\title{
MULTIVARIATE MEASUREMENT CONCEPT "INFORMATION WAR"
}

\section{Pronoza I. I.}

\section{INTRODUCTION}

With the establishment of the information society, and the rule of information technology, the term "information war" not only became symbolic and symbolic unit of journalistic and political vocabulary, but has been actively used as a separate category in the scientific discourse.

Modern XXI century is often called "the era of information technology," which takes place enormous contribution to the development of practices and combat information war, in which information security has become almost a panacea in solving the problems of the information society. The concept of modern information society is equivalent to the concept of "post-industrial society", given the growing political, social and military confrontation states the importance of information and huge investments in research centers. A series of post-industrial countries pay great importance of science, technology and information security of the country, well aware the importance of media influence on public consciousness as the regional and international levels ${ }^{1}$.

Modern domestic and Western scientific understanding of the information wars are far from complete and clarity. In the scientific literature and the Internet launched a great debate about the genesis of information warfare, the nature and means of implementation, methodology, analysis of theoretical, practical and comprehensive information "component" general scientific definition of this phenomenon. It is also very different in some socio-cultural and communication systems, and most importantly, about the subjects and objects of their own information confrontation. A detailed analytics on this topic is not fully available for general purposes and objectives of the study, or suffers frank populism and primarily designed for the mass market. Unfortunately, it must be noted in the scientific heritage.

Scientific work has as its priority partially fill this gap, and the problem is so urgent, serious and sharper than are currently geopolitical order problems are most involved in the structure and values of contemporary information warfare. Since the construction of a multipolar world, which involves creating around the country range of friendly nations that share its goals and values, it is

${ }^{1}$ Проноза I. I. Інформаційна війна: сутність та особливості прояву. Актуальні проблеми політики. Збірник наукових праць. Одеса. 2018.№ 61. С. 121. 
now a priority the idea of political and civil svitobuduvannya, as mentioned studies various forms, methods, tools and techniques of information warfare in the near future will only grow. Geopolitical, civilizational and ethological aspects of information warfare in modern scientific concepts is now the least studied.

\section{Information war: the nature and features of its manifestation}

Mankind at all stages of its establishment, faced with the problem of information warfare at all levels.

Information warfare - a communication technology on the impact of information and information systems of the enemy in order to achieve information superiority in the interests of national strategy, while protecting their own information and information systems. Information warfare - only the means, not the ultimate goal, similar bombardment - a means, not a goal. Information warfare can be used as a tool for strategic attack or counter ${ }^{2}$.

Such researchers as Zinoviev A.A., Dugin A.G., Korovin V.M. say that the new global war already in progress. It is not officially declared and hidden from the eyes of ordinary citizens, but leads humanity to profound changes in the balance of power in the world. The phenomenon described covert war became possible only in the development of modern information and communication technologies. Analysis of international experience shows that direct aggression today is no longer the only means of domination. In this regard modern science gradually focuses on the study of indirect forms of confrontation, focusing on information warfare.

The term "information war" currently has more journalistic in nature and have not received a steady recognition. These are ongoing discussions about what actually lies under this concept, as well as disputes over the accuracy and practical applicability of this term to the sphere of social relations, which is called informational confrontation or conflict of interest in the information sphere of social systems. Thus, a single scientific problem is the development and coordination of research and terminology.

In domestic and foreign science, there are many different and often mutually exclusive approaches to determining the conflicts that occur in modern information space. This diversity and inconsistency is a serious obstacle to the development of the theory of information warfare.

Study the information war is reflected in studies leading analysts from different countries such as Pocheptsov G., Razuvaev V., Tulchin G., Panarin I., Zawadzki J., Rastorguev S. Afanasyev G., Laynbarzhden , Knorih V., Coser L., Lasvel G., Brzezinski Z., Karpenko G., Lipkan V. et al.

${ }^{2}$ Кіслов Д. Сучасні медіа та інформаційні війни : монографія. Київ. міжнар. ун-т, ін-т журналістики. К. : МП Леся, 2013. С. 75. 
For the first time the term "information war" Ron T. taken in the report "weapons systems and information warfare", prepared by him in 1976. He emphasized that the information infrastructure is a key aspect of the US economy, at the same time, it becomes vulnerable purpose as in wartime and in peacetime ${ }^{3}$.

The first used the term "information war" American expert Thomas Rhone report prepared by them in 1976 for the company Boeing, and called "weapons systems and information warfare." Ron T. pointed out that the information infrastructure is a key component of the US economy. At the same time, it becomes vulnerable purpose, as in wartime and in peacetime. This report can be considered the first mention of the term "information war" 4 .

Today the concept of "information warfare" is defined differently. This is due to the ambiguity of the term «information warfare», which has led many discrepancies in his translations. The above concept can be interpreted as "information war", "information confrontation", "informationpsychological war." In particular, the information war is characterized as informational activities used political education (ie the state) to weaken, destroy other political entity; as information by competitors struggle between competitors; Information military conflict between two massive enemies such as armies and so on ${ }^{5}$.

The results of theoretical analysis can be stated that there are many substantiated concepts of information warfare and there is no generally accepted definition of this notion. This variety of approaches is primarily due to the complexity of the object of study and theoretical and methodological position of authors belonging to different scientific schools. This determines the emphasis of their attention on certain aspects of the problem.

Also, as part of a psychological paradigm of the information war is understood as the latent impact of information on individual, group and public consciousness by the methods of propaganda, misinformation and manipulation in order to create new views on social and political organization of society by changing the basic values and attitudes of the individual.

Exploring the information war in the context of psychological theories, V.A. Lysychkin and L.A. Shelepin indicate that its object is cognitiveemotional sphere of individuals, and the main purpose - managing intellectual, psychological and socio-cultural processes that element is mandatory acts

${ }^{3}$ Гриняев С. Концепция ведения информационной войны в некоторых странах мира. URL: http://www.soldiering.ru/psychology/conception_psywar.php

${ }^{4}$ Жарков Я. Інформаційно-психологічне протиборство (еволюція та сучасність) : монографія. Київ. нац. ун-т ім. Т. Шевченка. Київ: Віпол, 2013. С. 15

${ }^{5}$ Манойло А. В. Государственная информационная политика в особых условиях .М. 2013. С. 239. 
of unconscious influence individuals susceptible to influence and veiled following lines programmed behavior ${ }^{6}$

Psychological interpretation of this phenomenon also offer Volkogonov D.A., Zhiveynov N.I. and Karajan A.G. They combine information and psychological confrontation in one concept.

The first two scientists consider the information war as a system subversive ideological influences of imperialism aimed at the minds of people mainly through the field of social psychology ${ }^{7,8}$. In turn, Karajan A.G. adheres to the position that it is about information and psychological actions undertaken at the international or strategic, operational and tactical levels, both in peacetime and in wartime as in information and in the spiritual realm, among its soldiers or enemy ${ }^{9}$.

Ivan Kostyuk ${ }^{10}$ O. Saprykin ${ }^{11}$ P. Shevchuk ${ }^{12}$ researching the information wars, reveal the essence of information processes impact on society.

In turn, Vladimir Karpenko ${ }^{13}$ Ukrainian information space exploring the state covers the expansion of information, which neoimperialistychnyh to spread ideas, takes the form of Russian expansion into Ukraine's information space using their own ends Ukrainian media.

Noteworthy geopolitical approach under the provisions of which, the information war is interpreted in terms of interstate confrontation aimed at solving foreign policy objectives not through physical force, military equipment and weapons, and using sophisticated technologies koyersyvnoho control, which is the outward expression in the form diplomacy.

In modern scientific research singled out the circle of scientists who concentrate on social and communicative aspects of information warfare. Their research methodological principles differ in that the objective was

${ }^{6}$ Лисичкин В. А., Шелепин Л. А. Третья мировая (информационнопсихологическая) война. URL: http://malchish.org/lib/politics/infwar.htm.

${ }^{7}$ Гриняев С. Концепция ведения информационной войны в некоторых странах мира. URL: http://www.soldiering.ru/psychology/conception_psywar.php.

${ }^{8}$ Живейнов Н. И. Операция «РW»: «психологическая война» американских империалистов. М. 1996. 282 с.

${ }^{9}$ Караяни А. Г. Теория и практика психологической войны. Организация и проведение информационных операцій. URL: http://psyfactor.org/lib/psywar30.htm

${ }^{10}$ Костюк I.А. Інформаційні війни в контексті революційних подій в Україні. Актуальні проблеми соціальних комунікацій: матеріали студентської наукової конференції, 22 травня 2014 р. Київ. 2014. С. 57-60.

${ }^{11}$ Саприкін О. Інформаційна експансія, інформаційна війна та інформаційна атака у засобах масової інформації на прикладі Євро-2. Вісник Книжкової палати. 2013. № 1. C. $40-43$.

12 Шевчук П. Інформаційно-психологічна війна Росії проти України: як ій̆ протидіяти. Демократичне врядування. 2014. Вип. 13. URL: http://lvivacademy.com/visnik13/ zmist.html.

${ }^{13}$ Карпенко В. Інформаційний простір як чинник національної безпеки України. Українознавство: науковий громадсько-політичний культурно-мистецький релігійнофілософський педагогічний журнал. 2005. № 3. С. 182-192. 
dominated by information that becomes dominant influence in shaping sms reality and cognitive orientation, not people's minds.

This determination adhere M. Pavlyutenkova ${ }^{14}$ and D. A Swez ${ }^{15}$, by considering the information war is a communication technology which aims to achieve information superiority in the interests of national strategy ${ }^{16}$.

It is of interest to study this problem P. Spyga and R. Rudnik ${ }^{17}$, where scientists identify 4 approaches to the definition of this concept:

- first approach treats them as a set of political and legal, social, economic, psychological operations involving the capture of the information space, ousting the enemy from the information sphere, destroy his communications, deprivation means of communication and other similar purposes;

- the second approach, the information war - is the most severe form of confrontation in cyberspace, where the paramount importance of quality interactions such as uncompromising, high intensity korotkotryvalist sharp disputes and rivalry;

- on the third approach, information warfare is interpreted as a form of providing and maintaining military and security operations by using modern electronic media (digital emitters, satellite transmitters and other similar facilities used for military tasks);

- the fourth approach identifies information warfare cyber wars (conflict between technical systems).

Aside can not leave the idea of the conflict approach can be considered war analyzed from the perspective of military and political confrontation.

According to this, R. Shafransky study interprets the phenomenon as armed action against any system of knowledge and belief of the enemy, aimed hidden destructive influence on political decisions counterpart, resulting in poor coordination and efficiency of the process. The author emphasizes that the higher technological capabilities and more advanced communication sphere of the state, the more vulnerable it is in the information war $^{18}$.

As to the second of these directions, in the framework esplikuyetsya information war as a political confrontation.

Thus, in the A.V. Manoilo ideas, information warfare - political struggle, expressed in the form of information and psychological operations

${ }^{14}$ Павлютенкова М. Ю. Информационная война: реальная угроза или современный миф? Власть. М. 2001. № 12. С. 23.

${ }^{15}$ Швец Д. А. Информационное управление как технология обеспечения информационной безопасности. Массовая коммуникация и массовое сознание. - М., 2003. 34 с.

16 Манойло А. В. Государственная информационная политика в особых условиях. M. 2013. 290 c.

${ }^{17}$ Шпига П. С. Основні технології та закономірності інформаційної війни. Проблеми міжнародних відносин. 2014. Вип. 8. С. 328.

${ }^{18}$ Szafranski R. Theory of Information Warfare: Preparing For 2020 Official Site of “Airpower Journal”. URL: http://www.airpower.au.af.mil/airchronicles/apj/apj95/spr95_ files/szfran.htm. 
using information weapons and is the essential attribute of political leadership. Implementation of war is the strong influence of the contradictions inherent objective and take place at different levels of social organization. As a result it expected foreign and domestic manifestations of confrontation with a given level of intensity and deliberately organized a specific direction ${ }^{19}$.

The aforementioned position separates Y. Korolev, consider offering information confrontation in relation to regional political process. According to the author, his cause is due to the increase of capital or the powerful protection of their interests. Channel implementation of these strategies are media and political entities are counted as different social groups - the elite of the region and the federal government, audience appropriate media and mass social subject - the region's population as a whole.

State holistic vision of the studied phenomenon can be achieved through systematic approach presented in the works of S.P. Rastorguev, S.N. Bukharin, V.V. Tsyganov.

Basic concepts, used by S.P. Rastorguev - "information system", under which the information war is treated as a public / secret information systems influence one another for the purpose of deformation or destruction of the opposite side. They focus on delivering benefits not only in the material as a political and spiritual spheres, causing public cultural trauma, which leads the dismantling of state.

The systems view of the nature of information warfare expressed as S.N. Bukharin and V. Tsyganov.

They reduce the information war to the dynamic process taking place in a complex self-organizing system with many elements of communication between them are not deterministic and probabilistic nature. This war, according to the authors, resulting from advanced development of any component that requires reallocation of resources in their favor, and increased security. This entails contradictions with other parts of the system and removes it from equilibrium. The result is the transformation of information warfare system or disappearance and formation of a new organization.

In a significant number of scientific papers stated that the concept of "information warfare" mentioned in the directive of the Ministry of Defense of 21 December 1992 in the context of electronic warfare, and since 1996 has been extended term "strategic information warfare (information confrontation)» (Strategic Information Warfare ), because in this way it is presented in the report of the American corporation "Rand" "strategic information warfare. New Face of War »(« Strategic Information Warfare. A new face of War»).

${ }^{19}$ Манойло А. В. Государственная информационная политика в особых условиях. M. 2013. C. 187. 
In 2012, the official definition of "information war" appeared in Ukraine. The Strategic Defense Bulletin of Ukraine (number 771/2012), approved by Decree of the President of Ukraine of 29 December 2012, states: "Information warfare - a form of confrontation between actors (states, blocs, parties, etc.), which provides information on the impact of population the mass media, computer networks, etc. in order to develop appropriate public opinion, undermining the morale of society as a whole and its individual institutions "20.

Since this document is void and the Strategic Defense Bulletin of Ukraine in 2016 (№ 240/2016) ${ }^{21}$ definition of information warfare is no general interpretation of the term again transferred to the rank of contentious issues to vividly discussed in academic and political circles.

What scientists and military disadvantages see the term "information warfare" and why his rather inclined to believe professionalism is situated in a journalistic environment than a real term that can accurately and clearly reflect the properties latest confrontation?

The debate going on over the word "war." Besides him, often using "expansion", "confrontation", "conflict", "operation", "aggression", "impact", "terrorism", "attack", "sabotage", "occupation". Uncertainty timeframe zavualovanist purpose, a new character "weapons" and methods of warfare, the uncertainty relationship with law enforcement activities (information warfare in most cases accompanied by military phase of the conflict or is a prerequisite for it, but not always) leads researchers to abandon the use of the word "war "and resort to substitute.

However, it is now clear that such replacements should not be random: Each of the above terms has its scope of applicability.

Due to the fact that the information war is in an interdisciplinary and complex phenomenon, being in different dimensions, involves the use of techniques conglomerate, the question of overcoming the limited framework of certain theoretical constructs. On this basis, the author of this work finds the need for poliparadyhmalnoho approach to the study of information warfare as one of the aspects of modern social and political reality.

Given the current approach, information warfare should be considered in two main ways: in the broadest sense - as a new form of geopolitical rivalry between the parties (in this case it is advisable used the term "information confrontation") and in a narrower sense - to the sphere of armed struggle (here it is advisable Viko Figure ng term "struggle information").

${ }^{20}$ Стратегічний оборонний бюлетень України. Схвалено Указом Президента України від 29 грудня 2012 року № 771/2012 URL: http://zakon2.rada.gov.ua/laws/show/ 771/2012/paran16\#n16.

${ }^{21}$ Стратегічний оборонний бюлетень України. Введено в дію Указом Президента України від 6 червня 2016 року № 240/2016/ URL: http://www.president.gov.ua/documents/ 2402016-20137. 
Information confrontation aims to achieve public policy in peacetime and wartime. It is logical, objective proc catfish, which has always been and will in the relations between states irrespective of cooperation.

Information wrestling aims to gain and obtain information superiority over the enemy during the preparation and conduct of operations (combat). This involves the provision of a complete, accurate, reliable and timely information about the situation and opportunity management system to realize this advantage in operations (combat) forces (troops) ${ }^{22}$.

Due to its specificity struggle information is either independent view, or an integral part of any other kind of struggle (armed, ideological, economic, etc.). It is time - both civilian and

for war. The scope of information such tremendous struggle, its preparation and organization can not be spontaneous. It must be planned, systematic, based on deep research.

The content of the information fight. Considering the content of information to combat armed conflicts end of the XX century. Note that it is different depending on the stage of conflict.

During peacetime Information must fight secretive nature. Its main content is driving intelligence and political and psychological actions on the enemy, and take measures to ensure their information security. The growing role of play at this stage means of special software and mathematical impact on the resource of technical systems of the enemy. In this period can also be solved by the creation, development, maintaining the desired degree of readiness plans and working effectively combat the use of information resources of its troops (forces) as well as timely and reliable detection and neutralization of information influence opposing side.

IN threatening period added to these tasks and are performed in order to ensure the necessary effectiveness of planned operations (combat). Fully deployed infrastructure management system planned for the fighting groups of troops (forces) with a view to ensuring its maximum potaylyvosti.

To the peculiarities of information struggle in this period include:

- an extreme limitation of use capabilities and methods of information influence on the enemy;

- compliance with existing international law (such as electronic jamming prohibition of certain frequencies and systems Statute of the International Telecommunication Union and the Radio Regulations);

- close interaction between the various law enforcement agencies and government agencies in the event of information struggle.

Since the beginning of hostilities forces and means of combating carry information following tasks:

${ }^{22}$ Опорний конспект лекцій 3 дисципліни «Інформаційні війни» для студентів спеціальності 7.030404 «Міжнародна інформація» / Б.М.Юськів. Рівне: РІС КСУ, 2003. С. 28. 
- a massive influence on resource enemy and prevent a decrease in their combat capabilities of troops (forces) and effective use of their weapons and equipment using an opponent of similar products;

- carrying out measures to reduce the moral and psychological stability enemy and neutralize provide information that affects the moral and psychological state of its personnel;

- conducting information and intelligence and providing potaylyvosti important measures of its troops during the preparation and conduct of operations (combat).

During the combat action information in this period is extremely important to prevent accidental negative impact of its facilities on its information infrastructure facilities ${ }^{23}$.

Main features generalize the notion that the information war - "the highest level of information confrontation aimed at solving social, political, ideological and national, regional and other conflicts between nations, peoples, nations, classes and social groups by transnational corporations large-scale implementation of techniques and methods of violence information (information weapons).

Information warfare pursues global goal: the overthrow of the government changing political and legal regime inspiruvannya civil war as a source of permanent chaos and under controlled entities control this chaos.

Information warfare is not limited in space-time format, because its purpose is to establish a controlled force control algorithm through zastuvannya means of information war "24.

Most papers also noted that the information war - a "set of measures to informational influence on mass consciousness to change behavior and imposing their goals outside the circle of their interests, as well as protection against such influences; a form of informational confrontation between different actors (States, NGOs, economic and other structures), which involves a complex action damaging information area rival parties and protect their own information sphere" 25 .

The flow of information war accompanied by the use of information technologies' impact on information systems, with the aim of misleading mass or individual consciousness, disabling or desynchronization processes of governance and its constituents, notably the military" ${ }^{26}$.

${ }^{23}$ Карпенко В. Інформаційний простір як чинник національної безпеки України. Українознавство: науковий громадсько-політичний культурно-мистецький релігійнофілософський педагогічний журнал. 2005. № 3. С. 182-192.

24 Ліпкан В. А. Сучасний зміст інформаційних операцій проти України. Актуальні проблеми міжнародних відносин. 2011. Випуск 102 (Частина I). С. 34-43.

${ }^{25}$ Малик Я. Інформаційна війна і Україна. Демократичне врядування. 2005. Випуск 15. С. 45-49.

${ }^{26}$ Почепцов Г. Г. Інформаційна політика: навчальний посібник. 2-ге вид., стер. Київ: Знання, 2008. С. 559. 
As you can see, the definition highlights the complex nature activities, availability of a coherent strategy and global objectives impact primarily focus on destruction - in the areas of governance and security orientation to achieve information superiority over the enemy by simultaneous security of their information systems.

\section{Classification of information warfare}

Quite another problem to use the term "information warfare" is a constant variation or replacement of the first word, often within the meaning of "information" refers to the result of "psychological", "communication", "information technology", "unconventional" (not related to the use traditional weapons), "irregular", "virtual". In most cases such nomination only outline the major types and subtypes of the information war.

Typological series of information warfare, which has started a conversation M. Libiki, expanding every year. The division into species occurs mainly on a number of criteria:

- usually considered what to target,

- for what, with which instruments.

Generally distinguish the following types of information warfare:

1) command and management (confrontation or disorder to seize command and control mechanisms in the armed forces of the state);

2) Intelligence (confrontation with the information and intelligence kontrrozvidok);

3) economic and financial (information and economic war for control of trafficking, possession of the information necessary for an advantage over competitors)

4) electronic, hacker, cyberwar (influence of the means of electronic communication - radio, television and computer networks);

5) psychological (carried out by propaganda and manipulation to undermine public spirit, demoralization of the armed forces, to discredit cultural disorientation command of military forces or heads of legislative and executive); psychological war have their subspecies effects used in nature ${ }^{27}$ :

a) information and psychological (promoted certain ideas, attitudes, perceptions, beliefs, creates the foundation for positive or negative mental reaction mass);

b) psychogenic (accompanied by physical factors influences - sound, light, temperature, and the product of shock from some tragic events - death, destruction, etc; consequences - irrational behavior, emotional, emotions, depression, panic);

27 Чистоклетов Л. Г. Інформаційно-психологічні впливи як невід'ємна складова парадигми інформаційної безпеки. Науковий вісник Львівського державного університету внутрішніх справ. 2012. 2(1). С. 183-193. 
c) psychotropic (impact - lateral programming - is performed by transmitting information through unconscious perception; in the case of neurolinguistic programming - with special language programs to change the motivation of people and their behaviors);

6) Networking (complex information actions between social groups in social and professional networks for certain advantages in the economic, military, political, cultural and social confrontations ${ }^{28}$ :

a) high-tech network ( "modern high-tech digital communications that are based on a system of television, radio, the Internet, instant messengers, cellular, satellite and other modern communication and based on gadgets such as fixed computer devices, tablets, smartphones, devices of individual and group communication "29;

b) a network of high-Hume ( "modern high socio - humanitarian technology creation, storage, distribution and retrieval of information; these include SMM, SEO, targeting, contextual advertising, media viruses";

c) let the network sensor ( "Psy high current, making it possible to regulate and manage social communication processes at the level of social groups and individuals, typical in this respect is social psychology, psychoanalysis and applied NLP" ${ }^{30}$.

G. Pocheptsov in the book "Information policy", citing research W. Schwartau, suggests another classification information wars, built "in terms of objects from one person to the whole country." According to this criterion distinguished:

1) personal information war, which include various types of electronic manipulation of personal information;

2) corporate information warfare, which include situations of attack information systems;

3) global information war, where information is regarded as a national achievement by which others can hunt country ${ }^{31}$.

\section{CONCLUSIONS}

From the above analysis implies that the information war in the broadest sense is not allegorical way, it is a socio-political phenomenon and completely fall under the above definition of war. In its fully subject to all the general laws of war. Information warfare is the offensive and defensive components can be carried out in low intensity conflicts and conflicts with the

${ }^{28}$ Курбан О. В. Сучасні інформаційні війни в мережевому он-лайн просторі : навчальний посібник. Київ : ВІКНУ, 2016. С. 48.

${ }^{29}$ The same resourse.

30 Курбан О. В. Сучасні інформаційні війни в мережевому он-лайн просторі : навчальний посібник. Київ : ВІКНУ, 2016. С. 48.

${ }^{31}$ Курбан О. В. Сучасні інформаційні війни в мережевому он-лайн просторі : навчальний посібник. Київ : ВІКНУ, 2016. С. 50. 
use of weapons of mass destruction, at the tactical, operational and strategic levels. Information warfare is characterized by a number of inherent features. Unlike traditional wars, it is much broader in its goals, objectives and spheres of influence. In addition to security forces in this war involved political, financial, industrial and other structures.

Trend scaling information war steadily increases from the interstate character to mizhblokovoho. Nowadays information war is considered as the most efficient and "civilized" and "humane" way kolonializatsiyi one country to another.

\section{SUMMARY}

The article reveals some argued the concept of information warfare, provides a generalized definition of "information warfare."

The focus of the paper, the author focuses on the theoretical and methodological positions of scientists belonging to different academic schools and determine the information war through specific aspects of problems.

The author cites and describes different approaches to the classification of the information war and revealing their content.

\section{REFERENCES}

1. Гриняев С. Концепция ведения информационной войны в некоторых странах мира. URL: http://www.soldiering.ru/psychology/ conception_psywar.php.

2. Живейнов Н. И. Операция «PW»: «психологическая война» американских империалистов. М. 1996. 282 с.

3. Карпенко В. Інформаційний простір як чинник національної безпеки України. Українознавство: науковий громадсько-політичний культурно-мистеиький релігійно-філософський педагогічний журнал. 2005. № 3. С. 182-192.

4. Кіслов Д. Сучасні медіа та інформаційні війни : монографія. Київ. міжнар. ун-т, ін-т журналістики. К. : МП Леся, 2013. 239 с.

5. Костюк I.А. Інформаційні війни в контексті революційних подій в Україні. Актуальні проблеми сочіальних комунікацій: матеріали студентської наукової конферениїі, 22 травня 2014 р. Київ. 2014. С. 57-60.

6. Курбан О. В. Сучасні інформаційні війни в мережевому онлайн просторі : навчальний посібник. Київ : ВІКНУ, 2016. 286 с.

7. Лисичкин В. А., Шелепин Л. А. Третья мировая (информационно-психологическая) война. URL: http://malchish.org/lib/ politics/infwar.htm.

8. Ліпкан В. А. Сучасний зміст інформаційних операцій проти України. Актуальні проблеми міжнародних відносин. - 2011. Випуск 102 (Частина I). С. 34-43. 
9. Малик Я. Інформаційна війна i Україна. Демократичне врядування. 2005. Випуск 15. С. 45-49.

10. Манойло А. В. Государственная информационная политика в особых условиях .М. 2013. 290 с.

11. Михальченко И. А. Информационные войны на рубеже XXI века. Безопасность информационных технологий. 1998. № 3. С. 14-15.

12. Опорний конспект лекцій 3 дисципліни "Інформаційні війни" для студентів спеціальності 7.030404 «Міжнародна інформація». / Б.М.Юськів. Рівне: РІС КСУ, 2003. С. 28.

13. Павлютенкова М. Ю. Информационная война: реальная угроза или современный миф? Власть. М. 2001. № 12. С. 19-23.

14. Панарин И. Н. Информационная война и третий Рим. М. 2001. $244 \mathrm{c}$.

15. Почепцов Г. Г. Інформаційна політика: навчальний посібник. 2-ге вид., стер. Київ: Знання, 2008. 663 с.

16. Проноза I. I. Інформаційна війна: сутність та особливості прояву. Актуальні проблеми політики. Збірник наукових праць. Одеса. 2018.№ 61. С. 121.

17. Саприкін О. Інформаційна експансія, інформаційна війна та інформаційна атака у засобах масової інформації на прикладі Євро-2. Вісник Книжкової палати. 2013. № 1. С. 40-43.

18. Стратегічний оборонний бюлетень України. Введено в дію Указом Президента України від 6 червня 2016 року № 240/2016. URL: http://www.president.gov.ua/documents/2402016-20137.

19. Стратегічний оборонний бюлетень України. Схвалено Указом Президента України від 29 грудня 2012 року № 771/2012. URL: http://zakon2.rada.gov.ua/laws/show/771/2012/paran16\#n16.

20. Чистоклетов Л. Г. Інформаційно-психологічні впливи як невід'ємна складова парадигми інформаційної безпеки. Науковий вісник Львівського державного університету внутрішніх справ. 2012. 2(1). C. $183-193$.

21. Швец Д. А. Информационное управление как технология обеспечения информационной безопасности. Массовая коммуникация и массовое сознание. - М., 2003. 34 с.

22. Шевчук П. Інформаційно-психологічна війна Росії проти України: як їй протидіяти. Демократичне врядування. 2014. Вип. 13. URL: http://lvivacademy.com/visnik13/zmist.html.

23. Шпига П. С. Основні технології та закономірності інформаційної війни. Проблеми міжнародних відносин. 2014. Вип. 8. C. 326-339. 
24. Chris Zambelis Information Wars: Assessing the Social Media Battlefield in Syria. URL: http://www.isn.ethz.ch/Digital-Library/Articles/ Detail/?id=150989.

25. Fukushima K., Miyake S. Pattern Recognition, 1982. V. 15. P. 455-469.

26. Lenat D.B. The Nature of Heuristics. Artificial Intelligence, 1982. Vol. 19. P. 189-249.

27. Szafranski R. Theory of Information Warfare: Preparing For 2020 Official Site of “Airpower Journal”. URL: http://www.airpower.au.af.mil/ airchronicles/apj/apj95/spr95_files/szfran.htm.

\section{Information about the author:}

Pronoza I. I.,

Candidate of Political Sciences,

Senior Lecturer at the Department of Political Sciences and Law, South Ukrainian National Pedagogical University named after K. D. Ushynsky 26, Starofrankivska str., Odessa, 65020, Ukraine 